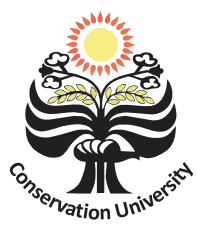

\title{
The Effect of Physical Activity agains the Telomere Length in the Leukocytes Cells of KONI Athletes
}

\author{
${ }^{\square}$ Endang Purwaningsih ${ }^{1}$, Titiek Djannatun ${ }^{2}$, Etty Widayanti ${ }^{1}$, Yulia Suciati ${ }^{3}$, Yenni \\ Zulhamidah $^{1}$
}

DOI: 10.15294/biosaintifika.v9i2.6207

${ }^{1}$ Department Anatomy, Faculty of Medicine, YARSI University, Jakarta, Indonesia ${ }^{2}$ Department Microbiology-Parasitology, Faculty of Medicine, YARSI University, Jakarta, Indonesia ${ }^{3}$ Department Biochemistry, Faculty of Medicine, YARSI University, Jakarta, Indonesia

\section{History Article \\ Received 6 December 2016 Approved 8 June 2017 Published 17 August 2017}

\section{Keywords}

physical exercise; telomere length; KONI; qPCR

\begin{abstract}
Telomeres are strands of non coding DNA at the ends of chromosomes that have the primary function to protect DNA from damage and maintain chromosomal stability. Physical exercise will increase the antioxidant activity can increase telomere proteins, lengthen telomeres and or protein networks associated with telomere so that the telomere remains long, or stopping telomere shortening. Telomere length was also associated with age. The purpose of the research was to determine telomere length of leukocyte cells in the KONI (Indonesian National Sports Committee) athletes in Jakarta. The research method is descriptive, by measuring telomere length using quantitative PCR on leukocyte cells. Samples are KONI athletes from several sports, including men and women athletes, with ages between 15-20 years. Used a control group (not athletes) is students of the Faculty of Medicine, University of YARSI. The results showed that there was no significant difference $(p>0.05)$ between telomere length group of athletes with the control group in both sexes. Similarly, telomere length between athlete male with female athletes also showed no significant difference $(p>0.05)$. It was concluded that physical exercise in athletes KONI at the age of 15- 20 years had no effect on telomere length in leukocytes. The results of this study provide information about the telomere length in Indonesian athletes at an early age.
\end{abstract}

\section{How to Cite}

Purwaningsih, E., Djannatun, T., Widayanti, E., Suciati, Y., \& Zulhamidah, Y. (2017). The Effect of Physical Activity Agains the Telomere Length in the Leukocytes Cells of KONI Athletes. Biosaintifika: Journal of Biology \& Biology Education, 9(2), 225-232.

(C) 2017 Universitas Negeri Semarang

\footnotetext{
Correspondence Author:

J1. Letjend Suprapto, Cempaka Putih Jakarta Pusat 10510

E-mail: endpurwaning@gmail.com
} 


\section{INTRODUCTION}

Telomeres are the ends of chromosomes that are non-coding DNA replication in eukaryotic cells, which in humans is a replication of hexanucleotide TTAGGG. Hexanucleotide a core protein of the complex telomere shelterin and is associated with telomere function (Sabenroth et al., 2015) Cloning DNA strand can be done thoroughly with their typical structure of telomeres and the enzyme telomerase. If the cells do not have telomerase, the cells were not able to double-stranded telomere DNA. Thus causing DNA strand telomeres become shorter (Theimer \& Feigon, 2006).

Telomere function is as a cover, which is essential for maintaining chromosome stability of recombination, fusion and degradation. Therefore, loss of telomere function might have had a great effect in the maintenance and integrity of chromosomes.

Telomere length can be used as an index of the biological age of a person or as biomarker of cell aging and can used to predict related incidence of morbidity and mortality (Laine et al., 2015). In addition to telomere length is often associated with the state of human health and at a certain age-related diseases in humans such as diseases related to the cardiovascular system (Hunt et al., 2008; Chen et al., 2011, Sabenroth et al., 2015)

Physical activity will increase the activity of antioxidant that can boost the protein telomere, extending telomeres and or tissue proteins associated with telomeres. Furthermore, physical activity can keep telomeres long stays or stop telomere shortening (Ludlow \& Roth, 2011).

The research objective was to determine telomere length in KONI athletes leukocyte cells in some sports include men and women athletes. Benefits of the research is include the information about the length of telomeres athletes at a young age and become a reference for further research related to telomere length at the same age or different age.

\section{METHODS}

The study used a descriptive survey by measuring the telomere length on leukocyte cell of KONI athletes from several branches of sports. The research was conducted in the Laboratory Clinic Prodia and Integrity Laboratory YARSI University, Jakarta.

Subjects were students of SMP / SMA Ra- gunan, South Jakarta, about 40 people i.e. 20 men and 20 women. The controls are students of the Faculty of Medicine, University of YARSI totaled 38 people, including 17 men and 21 women). The age ranged from 15-20 years. The sampling technique is random sampling and differentiates the active individuals exercising with individuals who are not actively exercising. The sample criteria is aged $15-20$ years, and healthy.Each subject of research conducted venous blood sampling as much as $5 \mathrm{cc}$, further isolation of lymphocytes and measurement of telomere length.

Samples were collected in tubes containing EDTA (Ethylene diamine tetra acid), then dilution with PBS solution (Phosphate Buffered Saline). Tubes labeled EDTA, then blood EDTA samples were rocked to prevent blood clotting. EDTA blood was transferred to a special tube and added a solution of PBS with comparing 1: 1. Mixture of blood EDTA (Ethylene diamine tetra Acid,) and PBS were transferred into tubes already containing Ficoll, then centrifuged at a speed of $400 \mathrm{~g}$, for 10 minutes. The middle layer (monocytes) were taken and transferred to a new tube, then added Ficoll and centrifuge back on the speed of $100 \mathrm{~g}$ for 10 minutes. Centrifugation is done 2 times.

Measurement of telomere length were calculated using quantitative PCR (O'Collaghan et al., 2011), includes the step of DNA isolation, measuring the quality and quantity of DNA and genotyping. Measurement of relative elomere length is relatively proceed with the method Cawthon (2002).

DNA was extracted using the QIAamp DNA blood mini kit (Qiagen, Germany) according to the protocol indicated on the kit DNA is then stored in a freezer at $-20^{\circ} \mathrm{C}$.

The quality and quantity of DNA were analyzed using a spectrophotometer NanoDrop ND1000. This measurement is important to do in order to determine the concentration of DNA to be used in PCR and sequencing.

PCR (polymerase chain reaction) is a technique or method of reproduction (replication) enzymatic DNA without using organisms. With this technique, the DNA can be produced in large quantities at relatively short time so as to facilitate a variety of other techniques that use DNA. PCR was performed to determine the length of telomeres through repetition TTAGGG generated. Here is a primer sequence that was used to observe telomere length.

Telomere length data were analyzed by ANOVA followed by multiple comparison test using SPSS 20 version 
Table 1. Oligomere used to measure the length of telomeres in human and rodent

\begin{tabular}{|c|c|c|c|c|}
\hline & $\begin{array}{l}\text { Oligomer } \\
\text { Name }\end{array}$ & Species & Oligomer sequence $\left(5^{\prime}-3^{\prime}\right)$ & $\begin{array}{l}\text { Ampli- } \\
\text { con size }\end{array}$ \\
\hline \multirow[t]{2}{*}{$\begin{array}{l}\text { Stan- } \\
\text { dards }\end{array}$} & $\begin{array}{l}\text { Telomere } \\
\text { standard }\end{array}$ & $\begin{array}{l}\text { Human/ } \\
\text { rodent }\end{array}$ & (TTAGGG)14 & $84 \mathrm{bp}$ \\
\hline & $\begin{array}{c}\text { 36B4 } \\
\text { standard }\end{array}$ & Human & $\begin{array}{l}\text { CAGCAAGTGGGAAGGTGTAATCCGTCTCCA- } \\
\text { CAGACAAGGCCAGGACTCGTTTG TACCCGTTGAT- } \\
\text { GATAGAATGGG }\end{array}$ & $75 \mathrm{bp}$ \\
\hline \multirow[t]{8}{*}{$\begin{array}{c}\text { PCR } \\
\text { Primers }\end{array}$} & teloF & $\begin{array}{l}\text { Human/ } \\
\text { rodent }\end{array}$ & $\begin{array}{l}\text { CGGTTTGTTTGGGTTTGGGTTTGGGTTTGGG } \\
\text { TTTGGGTT }\end{array}$ & $>76 \mathrm{bp}$ \\
\hline & teloR & $\begin{array}{l}\text { Human/ } \\
\text { rodent }\end{array}$ & GGCTTGCCTTACCCTTACCCTTACCC TTACCCTTACCCT & \\
\hline & $36 \mathrm{~B} 4 \mathrm{~F}$ & Human & CAGCAAGTGGGAAGGTGTAATCC & $75 \mathrm{bp}$ \\
\hline & 36B4R & Human & CCCATTCTATCATCAACGGGTACAA & \\
\hline & b-globinF & Human & GCTTCTGACACAACTGTGTTCACTAGC & $82 \mathrm{bp}$ \\
\hline & b-globinR & Human & CACCAACTTCATCCACGTTCACC & \\
\hline & 36B4F & Rodent & ACTGGTCTAGGACCCGAGAAG & $78 \mathrm{bp}$ \\
\hline & 36B4R & Rodent & TCAATGGTGCCTCTGGAGATT & \\
\hline
\end{tabular}

(O'Collaghan et al., 2011),

This research has been getting Description Escaped Airworthiness Conduct of Research Ethics Committee, Research YARSI with No. 004 / KEP-UY / BIA / V / 2014 dated May 9, 2014

\section{RESULTS AND DISCUSSION}

Measurement of telomere length is done by creating a standard curve of telomeres compared to the standard curve Beta-globin with Quantitative PCR methods (O'Collaghan et al., 2011) and was followed by measuring the relative telomere length by calculating the ratio between telomere to single copy gene (T / S) Quantitative PCR method refers to a method of Cawthon (2002). The results of measurements of the relative telomere length of 38 samples are presented in Table 1. As supporting data presented data from anthropometric examination (Table 2, 3, and 4)

Statistical analysis with Levence test showed no difference between groups of athletes with the control group with a significance value of $p>0.05$. By sex obtained telomere length between male athletes with female athletes did not show a difference with a significance value of $p>$ 0.05).

Telomeres are nucleoprotein structures located at the ends of chromosomes of eukaryotic cells. Telomere length can be shortened with age and is involved in cellular aging. Therefore, the telomere length is a biomarker for aging (Mather et al., 2011). Telomeres consist of nucleotides TTAGGG replication. In humans, there is a repeat of 2000
Table 2. Relative telomere length value in athlete and control group leukocyte (ratio T / S)

\begin{tabular}{|c|c|c|c|c|}
\hline \multirow{2}{*}{$\begin{array}{c}\text { Rep- } \\
\text { etition }\end{array}$} & \multicolumn{2}{|c|}{ Athlete Group } & \multicolumn{2}{|c|}{ Control Group } \\
\hline & Male & Female & Male & Female \\
\hline 1 & 0.76 & 0.77 & 0.82 & 0.82 \\
\hline 2 & 0.75 & 0.90 & 0.85 & 0.80 \\
\hline 3 & 0.75 & 0.78 & 0.82 & 0.81 \\
\hline 4 & 0.79 & 0.76 & 0.83 & 0.79 \\
\hline 5 & 0.78 & 0.79 & 0.82 & 0.82 \\
\hline 6 & 0.78 & 0.84 & 0.83 & 0.80 \\
\hline 7 & 0.78 & 0.79 & 0.82 & 0.79 \\
\hline 8 & 0.78 & 0.80 & 0.82 & 0.78 \\
\hline 9 & 0.88 & 0.79 & 0.80 & 0.80 \\
\hline 10 & 0.79 & 0.79 & 0.81 & 0.82 \\
\hline 11 & 0.78 & 0.81 & 0.74 & 0.82 \\
\hline 12 & 0.79 & 0.84 & 0.82 & 0.86 \\
\hline 13 & 0.76 & 0.80 & 0.78 & 0.83 \\
\hline 14 & 0.80 & 0.81 & 0.79 & 0.84 \\
\hline 15 & 0.83 & 0.83 & 0.80 & 0.81 \\
\hline 16 & 0.80 & 0.83 & 0.83 & 0.81 \\
\hline 17 & 0.82 & 0.85 & 0.86 & 0.84 \\
\hline 18 & 0.81 & 0.85 & & 0.81 \\
\hline 19 & 0.78 & 0.82 & & 0.87 \\
\hline 20 & 0.79 & 0.86 & & 1.04 \\
\hline 21 & & & & 0.93 \\
\hline Mean & 0.7900 & 0.8156 & 0.8141 & 0.8329 \\
\hline $\mathrm{SD}$ & 0.02974 & 0.03456 & 0.02740 & 0.05789 \\
\hline
\end{tabular}


In this study, the sample used is young people aged between 17-20 years, male and female gender, include athletes with some sports include athletics, football, volleyball, hangars, and boxing. Measurement of telomere length is taken from the cell leukocyte. The study by some researchers previously reported that telomere length at the individual has a different telomere length in different tissues or organs, such as the kidneys, liver, lungs or blood cells, lymphocyte cells have telomere length varied. Similarly, different species, length of telomeres is also different in different species (Cherif et al., 2003)

Various studies show that the influence of exercise to delay aging and prolong life. People who regularly exercise generally held steady despite the young age of aging. Compared with tho- se who did not exercise, athletes runners had cells that looked much younger when observed under a microscope. According to Ludlow and Roth (2011), physical exercise will increase the activity of antioxidant that can boost the protein telomere, extending telomeres and or tissue proteins associated with telomeres. Sport / physical activity keep telomeres long stays or stop telomere shortening. Studies on 69 men and women volunteer aged 50-70 years showed that regular physical activity can maintain to the telomere length (Ludlow et al., 2008; Collin et al., 2003)

The results of this research showed that telomere length in KONI athletes leukocytes did not differ with the control group. This research was supported by previous studies reported that the leukocyte telomere length in cells of young

Table 3. Data of weight / height in a control and athlete group

\begin{tabular}{|c|c|c|c|c|c|c|c|c|}
\hline \multirow{3}{*}{ Repetition } & \multicolumn{4}{|c|}{ Athlete group } & \multicolumn{4}{|c|}{ Control Group } \\
\hline & \multicolumn{2}{|c|}{ Male } & \multicolumn{2}{|c|}{ Female } & \multicolumn{2}{|c|}{ Male } & \multicolumn{2}{|c|}{ Female } \\
\hline & $\begin{array}{c}\text { Body } \\
\text { Weight } \\
(\mathrm{kg})\end{array}$ & $\begin{array}{l}\text { Body } \\
\text { height } \\
(\mathrm{cm})\end{array}$ & $\begin{array}{c}\text { Body } \\
\text { Weight } \\
\text { (kg) }\end{array}$ & $\begin{array}{l}\text { Body } \\
\text { height } \\
(\mathrm{cm})\end{array}$ & $\begin{array}{c}\text { Body } \\
\text { Weight } \\
(\mathrm{kg})\end{array}$ & $\begin{array}{l}\text { Body } \\
\text { height } \\
(\mathrm{cm})\end{array}$ & $\begin{array}{c}\text { Body } \\
\text { Weight } \\
\text { (kg) }\end{array}$ & $\begin{array}{c}\text { Body } \\
\text { height } \\
\text { (cm) }\end{array}$ \\
\hline 1 & 60 & 170 & 47 & 158 & 91 & 187 & 39 & 155 \\
\hline 2 & 53 & 156 & 49 & 167 & 83 & 169 & 46 & 152 \\
\hline 3 & 68 & 168 & 46 & 158 & 66 & 175 & 52 & 157 \\
\hline 4 & 58 & 162 & 82 & 172 & 70 & 165 & 56 & 156 \\
\hline 5 & 59 & 165 & 68 & 167 & 56 & 160 & 50 & 161 \\
\hline 6 & 62 & 168 & 60 & 169 & 160 & 160 & 58 & 157 \\
\hline 7 & 64 & 169 & 46 & 155 & 69 & 172 & 61 & 163 \\
\hline 8 & 74 & 185 & 44 & 158 & 62 & 165 & 44 & 149 \\
\hline 9 & 60 & 165 & 46 & 150 & 110 & 176 & 49 & 159 \\
\hline 10 & 55 & 167 & 69 & 169 & 51,5 & 170 & 42 & 158 \\
\hline 11 & 54 & 174 & 62 & 165 & 77,5 & 171 & 61 & 158 \\
\hline 12 & 67 & 176 & 55 & 163 & 96 & 165 & 61 & 155 \\
\hline 13 & 54.5 & 176 & 58 & 170 & 80 & 173 & 55 & 153 \\
\hline 14 & 53 & 163 & 71 & 154 & 87 & 174 & 51 & 155 \\
\hline 15 & 57 & 170 & 77 & 172 & 66 & 166 & 60 & 153 \\
\hline 16 & 66 & 178 & 60 & 174 & 67 & 178 & 46 & 161 \\
\hline 17 & 62 & 168 & 72 & 175 & 87 & 184 & 49 & 159 \\
\hline 18 & 60 & 164 & 46 & 155 & & & 49 & 158 \\
\hline 19 & 61 & 171 & 50 & 168 & & & 58 & 163 \\
\hline 20 & 50 & 163 & 48 & 161 & & & 60 & 160 \\
\hline 21 & 45 & 154 & & & & & 60 & 163 \\
\hline Mean & 59.40 & 168.19 & 57.80 & 164.00 & 81.12 & 171.18 & 52.71 & 157.38 \\
\hline SD & 6.73 & 7.18 & 11.91 & 7.42 & 25.33 & 7.54 & 6.92 & 3.81 \\
\hline
\end{tabular}


athletes with an average age of 20.6 years is not different from the control group, are volunteers who are not actively doing physical activity. Instead of continuous exercise in athletes older the average age of 51.6 years, showed that the telomeres are longer than those without exercise (Werner et al., 2008).

Another study on adolescent group Caucasians and African Americans ages 14 to 18 years also show telomere length (ratio T / S) does not difference compared to the control group. But the telomere length in Afrika.-American race is greater than Caucasians. It shows that the race can affect telomere length, whereas adipose tissue is not related to telomere length at this age. Physical activity causes the anti-aging effects are quite strong at a young age, particularly in women (Zhu et al., 2011)
Moderate physical exercise or aerobics, especially in women can maintain telomere length or increasing telomere length than those who are inactive. It is especially in women over the age of 40 years. Regular physical activity nothing to do with a decrease in oxidative stress and inflammation as well help prevent the onset of chronic diseases. It has been reported also that telomere length is influenced by various factors such as age, sex, race, smoking, physical activity, socioeconomic status, obesity, intake of multivitamins, alcohol consumption and hormone replacement therapy despite inconsistent findings ( Enokido et al., 2014)

Relative telomere length (ratio $\mathrm{T} / \mathrm{S}$ ) at a young age (22-27 years) and elderly (66-77 years) between the group of athletes with non-athletes men have also been reported. At a young age, te-

Table 4. Waist circumference ratio data (LPI) $\mathrm{cm}$ ) and Pelvic circumference (LPA) $\mathrm{cm}$ ) data of athletes and the control group

\begin{tabular}{cccccccccc}
\hline \multirow{3}{*}{ Repetition } & \multicolumn{3}{c}{ Athlete Group } & \multicolumn{3}{c}{ Control Group } \\
\cline { 2 - 9 } & \multicolumn{3}{c}{ Male } & \multicolumn{2}{c}{ Female } & Male & \multicolumn{3}{c}{ Female } \\
\cline { 2 - 9 } Wc & Pr & Wc & Pr & Wc & Pr & Wc & Pr \\
\hline 1 & 77 & 85 & 76 & 90 & 107 & 103 & 63 & 83 \\
2 & 70 & 75 & 82 & 88 & 93 & 104 & 87 & 90 \\
3 & 90 & 93 & 62 & 83 & 89 & 93 & 77 & 83 \\
4 & 77 & 85 & 96 & 112 & 87 & 97 & 46 & 89 \\
5 & 73 & 83 & 70 & 97 & 72 & 95 & 87.5 & 98 \\
6 & 85 & 70 & 76 & 94 & 77 & 93 & 82,5 & 98 \\
7 & 82 & 90 & 68 & 87 & 84 & 96 & 89 & 102 \\
8 & 83 & 92 & 67 & 85 & 79 & 98 & 71 & 84 \\
9 & 72 & 87 & 69 & 88 & 98 & 114 & 69 & 94 \\
10 & 79 & 86 & 77 & 102 & 26 & 87 & 76 & 81 \\
11 & 76 & 86 & 80 & 89 & 88 & 103 & 98 & 96 \\
12 & 85 & 95 & 75 & 83 & 108 & 112 & 74 & 95 \\
13 & 80 & 88 & 78 & 83 & 101 & 102 & 75 & 97 \\
14 & 70 & 89 & 88 & 95 & 103 & 109 & 69 & 86 \\
15 & 76 & 93 & 86 & 95 & 90 & 95 & 78 & 95 \\
16 & 76 & 95 & 81 & 88 & 87 & 89 & 66 & 89 \\
17 & 78 & 96 & 82 & 89 & 89,5 & 107 & 69 & 89 \\
18 & 76 & 93 & 68 & 82 & & & 70 & 87 \\
19 & 80 & 93 & 73 & 83 & & & 76 & 97 \\
20 & 69 & 88 & 71 & 83 & & & 77 & 99 \\
21 & 65 & 85 & & & & & 76 & 96 \\
Mean & 77.10 & 87.95 & 76.25 & 89.80 & 86.97 & 99.82 & 75.05 & 91.81 \\
SD & 6.05 & 6.47 & 8.23 & 7.61 & 18.69 & 7.80 & 10.76 & 6.18 \\
\hline & & Notes: Wc $=$ waist circumference; Pr $=$ pelvic ring &
\end{tabular}


lomere length athletes are no different from nonathletes, while in old age, telomere length was significantly different. Group of athletes had longer telomeres than non-athletes (Osthus et al., 2012)

Results of a meta-analysis on the effect of physical activity on telomere length have also been reported. From a meta-analysis of randomized conducted 35 research results convering 41 329 samples reported that 20 the results showed no difference between telomere length group of athletes with the control group, while 15 other research showed significant differences (Mundstock et al., 2015).

In this study, telomere length between male athletes with female athletes is the same. There are no reports of previous studies related to telomere length among women athletes to male athletes. It has been reported that in male athletes . telomere length at a young age did not diffe- rent from the control group and physical activity in athletes is not related to the relative telomere length in later life (Laine et al., 2015)

In individual non-athletes, researchers previously reported that telomere length between men and women did not differ significance. It is reported that telomere length-related changes with increasing age and male gender. There were no significant differences in telomere length between male and female. It was further reported also that socio-economic status, poor, diet and smoking habits may be associated with one's biological aging process. (Hunt et al., 2008; Shiels et al., 2011).

Things contradictions reported by other studies that found that newborn female babies had longer telomere than male babies. (Aubert et al., 2012). This is supported by other studies that also reported the difference in telomere length

Table 5. Thick fat data in athletes group and the control group

\begin{tabular}{|c|c|c|c|c|c|c|c|c|c|c|c|c|}
\hline \multirow{3}{*}{$\begin{array}{l}\text { Repe- } \\
\text { tition }\end{array}$} & \multicolumn{6}{|c|}{ Athlete Group } & \multicolumn{6}{|c|}{ Control Group } \\
\hline & \multicolumn{3}{|c|}{ Male } & \multicolumn{3}{|c|}{ Female } & \multicolumn{3}{|c|}{ Male } & \multicolumn{3}{|c|}{ Female } \\
\hline & $\begin{array}{l}\text { Bi- } \\
\text { ceps }\end{array}$ & $\begin{array}{l}\text { Tri- } \\
\text { ceps }\end{array}$ & S.Iliaca & $\begin{array}{l}\text { Bi- } \\
\text { ceps }\end{array}$ & $\begin{array}{l}\text { Tri- } \\
\text { ceps }\end{array}$ & S.Iliaca & $\begin{array}{l}\text { Bi- } \\
\text { ceps }\end{array}$ & $\begin{array}{l}\text { Tri- } \\
\text { ceps }\end{array}$ & S.Iliaca & $\begin{array}{l}\text { Bi- } \\
\text { ceps }\end{array}$ & $\begin{array}{l}\text { Tri- } \\
\text { ceps }\end{array}$ & S.Iliaca \\
\hline 1 & 6 & 5 & 4 & 5 & 7 & 9 & 6 & 9 & 14 & 6 & 11 & 17 \\
\hline 2 & 5 & 4 & 6 & 5 & 6 & 6 & 10 & 14 & 20 & 7 & 9 & 11 \\
\hline 3 & 4 & 4 & 5 & 6 & 8 & 8 & 5 & 7 & 7 & 4 & 6 & 11 \\
\hline 4 & 5 & 6 & 16 & 10 & 14 & 15 & 11 & 14 & 18 & 6 & 9 & 14 \\
\hline 5 & 5 & 5 & 7 & 10 & 14 & 15 & 11 & 12 & 14 & 8 & 13 & 13 \\
\hline 6 & 5 & 5 & 5 & 7 & 14 & 10 & 5 & 11 & 12 & 9 & 28 & 18 \\
\hline 7 & 6 & 5 & 5 & 6 & 9 & 8 & 6 & 11 & 16 & 6 & 8 & 10 \\
\hline 8 & 4 & 6 & 5 & 6 & 9 & 7 & 5 & 8 & 12 & 10 & 13 & 16 \\
\hline 9 & 5 & 4 & 6 & 6 & 11 & 10 & 7 & 22 & 26 & 9 & 13 & 15 \\
\hline 10 & 5 & 6 & 6 & 6 & 12 & 9 & 3 & 4 & 6 & 6 & 9 & 8 \\
\hline 11 & 2 & 5 & 6 & 5 & 5 & 10 & 5 & 9 & 18 & 6 & 9 & 18 \\
\hline 12 & 6 & 5 & 6 & 4 & 5 & 5 & 12 & 19 & 28 & 12 & 18 & 19 \\
\hline 13 & 5 & 6 & 5 & 5 & 4 & 5 & 8 & 6 & 15 & 10 & 19 & 17 \\
\hline 14 & 4 & 6 & 6 & 9 & 9 & 10 & 7 & 12 & 13 & 8 & 14 & 13 \\
\hline 15 & 5 & 6 & 6 & 5 & 5 & 10 & 5 & 8 & 10 & 9 & 11 & 15 \\
\hline 16 & 6 & 10 & 7 & 3 & 5 & 5 & 4 & 7 & 6 & 5 & 12 & 11 \\
\hline 17 & 4 & 8 & 6 & 5 & 6 & 5 & 8 & 15 & 19 & 6 & 9 & 13 \\
\hline 18 & 4 & 6 & 5 & 3 & 5 & 5 & & & & 6 & 8 & 15 \\
\hline 19 & 5 & 5 & 5 & 4 & 5 & 5 & & & & 11 & 15 & 21 \\
\hline 20 & 5 & 5 & 6 & 3 & 5 & 5 & & & & 4 & 10 & 15 \\
\hline 21 & 4 & 6 & 6 & & & & & & & 11 & 16 & 16 \\
\hline Mean & 4.76 & 5.62 & 6.14 & 5.65 & 7.90 & 8.10 & 6.94 & 11.06 & 14.94 & 7.57 & 12.38 & 14.57 \\
\hline SD & 0.94 & 1.36 & 2.37 & 2.06 & 3.43 & 3.14 & 2.68 & 4.70 & 6.25 & 2.36 & 4.94 & 3.25 \\
\hline
\end{tabular}


between both the sexes. It was reported that the white blood cells, women have longer telomeres than men (Nawrot et al., 2004; Barrett \& Richardson, 2011, Gardner et al., 2014; Dalgard et al., 2015)

Physical activity spare time can increase telomere length of about 200 nucleotides in both men and women compared to inactive. Not reported differences in telomere length in male athletes and female athletes. Physical activity can be potentially as anti-aging. In addition to, intensive physical activity in men aged 20-30 years at least 10 years can extend the telomeres (Cherkas et al., 2008; Sabenroth et al., 2015).

Regular physical exercise can maintain telomere length, induces anti-aging, and has the effect of protective. Besides physical activity in men and women athlete with an average age of 20 years have anti-apoptotic effects on endothelial cells. Physical exercise will increase the activity of antioxidant that can boost the protein telomere, extending telomeres and or proteins associated with telomeres. Sport/physical activity keep telomeres long stays or stop telomere shortening. Studies on 69 volunteer men and women aged 50-70 years showed that regular physical activity to maintain telomere length (Ludlow et al., 2008; Ludlow \& Roth, 2011; Werner et al., 2008)

In this study, the sample used is young people aged between 17-20 years, including male and female. Measurements taken from the telomere length of leukocyte cells in healthy individuals. A previous study reported that telomere length in individuals to variations, i.e. different organs have different telomere length, such as the kidneys, liver, lungs or blood cells, lymphocyte cells have telomere length varied. Similarly, different species, length of telomeres is also different (Cherif et al., 2003).

Telomere length associated with a person's nutritional status. Assessment of nutritional status is calculated values between body weight and height person who is described as a person's body mass index. Overview nutritional status among athletes and non athletes depicted in Table 3.

Total fat content of a person's body is important to know because it determines whether a person can be classified as obese or not obese. Percentage of body fat in athletes and control group illustrated in Table 4 and 5.

Levels of body fat based on waist circumference and sex in athletes eligible men and women classified as normal because the percentage is greater than non-athletes in the same age group. Physical activity in athletes can prevent the accumulation of body fat (Azwar, 2004). A previous study reported that obesity is associated with increased oxidative stress, inflammation and telomere shortening is associated with increased body mass index and increased waist circumference and hip circumference, especially in women (Kim et al., 2010)

The results of this study provide information about the telomere length in Indonesian athletes at an early age and provide information to the public about the effect of exercise on telomere length that can become the biomarker of the aging process.

\section{CONCLUSIONS}

Telomere length in KONI athletes in the 1517 age equal to the length of telomeres with non athletes at the same age level. The length of telomeres in women athletes to male athletes are the same.

\section{ACKNOWLEDGMENT}

The author would like to thank the Directorate General of Higher Education through research funding Decentralization Higher Education Research Advancement on financial assistance for the implementation of this study and Laboratory Clinic Prodia for the assitanced in the procrurement of reagents and facilities to conduct researsch

\section{REFERENCES}

Aubert, G., Baerlocher, G. M., Vulto, I., Poon, S. S., \& Lansdorp, P. M. (2012). Collapse of telomere homeostasis in hematopoietic cells caused by heterozygous mutations in telomerase genes. PLoS Genet, 8(5), e1002696.

Azwar, A. (2004). Tubuh sehat ideal dari segi kesehatan. In Makalah disampaikan pada Seminar Kesehatan Obesitas, Senat Mahasiswa Fakultas Kesehatan Masyarakat UI, Sabtu (Vol. 15, pp. 1-7).

Barrett, E. L., \& Richardson, D. S. (2011). Sex differences in telomeres and lifespan. Aging cell, 10(6), 913-921.

Cawthon, R. M. (2002). Telomere measurement by quantitative PCR. Nucleic acids research, 30(10), e47-e47.

O'Callaghan, N. J., \& Fenech, M. (2011). A quantitative PCR method for measuring absolute telomere length. Biological procedures online, 13(1), 3.

Chen, W., Kimura, M., Kim, S., Cao, X., Srinivasan, S. R., Berenson, G. S., ... \& Aviv, A. (2011). Longitudinal versus cross-sectional evaluations of leukocyte telomere length dynamics: agedependent telomere shortening is the rule. Journals of Gerontology Series A: Biomedical Sciences and Medical Sciences, 66(3), 312-319. 
Cherif, H., Tarry, J. L., Ozanne, S. E., \& Hales, C. N. (2003). Ageing and telomeres: a study into organ-and gender-specific telomere shortening. Nucleic acids research, 31(5), 1576-1583.

Cherkas, L. F., Hunkin, J. L., Kato, B. S., Richards, J. B., Gardner, J. P., Surdulescu, G. L., ... \& Aviv, A. (2008). The association between physical activity in leisure time and leukocyte telomere length. Archives of internal medicine, 168(2), 154158.

Collins, M., Renault, V., Grobler, L. A., Gibson, A. S. C., Lambert, M. I., Derman, E. W., ... \& Mouly, V. (2003). Athletes with exercise-associated fatigue have abnormally short muscle DNA telomeres. Medicine \& Science in Sports \& Exercise, 35(9), 1524-1528.

Dalgård, C., Benetos, A., Verhulst, S., Labat, C., Kark, J. D., Christensen, K., .. \& Aviv, A. (2015). Leukocyte telomere length dynamics in women and men: menopause vs age effects. International journal of epidemiology, 44(5), 1688-1695.

Enokido, M., Suzuki, A., Sadahiro, R., Matsumoto, Y., Kuwahata, F., Takahashi, N., ... \& Otani, K. (2014). Parental care influences leukocyte telomere length with gender specificity in parents and offsprings. BMC psychiatry, 14(1), 277.

Gardner, M., Bann, D., Wiley, L., Cooper, R., Hardy, R., Nitsch, D., ... \& Bekaert, S. (2014). Gender and telomere length: systematic review and meta-analysis. Experimental gerontology, 51, 15-27.

Hunt, S. C., Chen, W., Gardner, J. P., Kimura, M., Srinivasan, S. R., Eckfeldt, J. H., ... \& Aviv, A. (2008). Leukocyte telomeres are longer in African Americans than in whites: the national heart, lung, and blood institute family heart study and the Bogalusa heart study. Aging cell, 7(4), 451-458.

Kim, S., Parks, C. G., DeRoo, L. A., Chen, H., Taylor, J. A., Cawthon, R. M., \& Sandler, D. P. (2009). Obesity and weight gain in adulthood and telomere length. Cancer Epidemiology and Prevention Biomarkers, 18(3), 816-820.

Laine, M. K., Eriksson, J. G., Kujala, U. M., Raj, R., Kaprio, J., Bäckmand, H. M., ... \& Sarna, S. (2015). Effect of intensive exercise in early adult life on telomere length in later life in men. Journal of sports science \& medicine, 14(2), 239.

Ludlow, A. T., Zimmerman, J. B., Witkowski, S., Hearn, J. W., Hatfield, B. D., \& Roth, S. M. (2008). Relationship between physical activity level, telomere length, and telomerase activity.
Medicine and science in sports and exercise, 40(10), 1764.

Ludlow, A. T., \& Roth, S. M. (2011). Physical activity and telomere biology: exploring the link with aging-related disease prevention. Journal of aging research, 2011.

Mather, K., Milburn, P., Parslow, R., Anstey, K., Jorm, A., Christensen, H., \& Easteal, S. (2007). Is telomere length a biomarker of ageing?. Australasian Journal on Ageing, 26(2), A48-A49.

Mundstock, E., Zatti, H., Louzada, F. M., Oliveira, S. G., Guma, F. T., Paris, M. M., ... \& Sarria, E. E. (2015). Effects of physical activity in telomere length: systematic review and meta-analysis. Ageing research reviews, 22, 72-80.

Nawrot, T. S., Staessen, J. A., Gardner, J. P., \& Aviv, A. (2004). Telomere length and possible link to $X$ chromosome. The Lancet, 363(9408), 507-510.

Østhus, I. B. Ø., Sgura, A., Berardinelli, F., Alsnes, I. V., Brønstad, E., Rehn, T., ... \& Nauman, J. (2012). Telomere length and long-term endurance exercise: does exercise training affect biological age? A pilot study. PloS one, 7(12), e52769.

Saßenroth, D., Meyer, A., Salewsky, B., Kroh, M., Norman, K., Steinhagen-Thiessen, E., \& Demuth, I. (2015). Sports and exercise at different ages and leukocyte telomere length in later lifeData from the Berlin Aging Study II (BASE-II). PloS one, 10(12), e0142131.

Shiels, P. G., McGlynn, L. M., MacIntyre, A., Johnson, P. C., Batty, G. D., Burns, H., ... \& McGinty, A. (2011). Accelerated telomere attrition is associated with relative household income, diet and inflammation in the pSoBid cohort. PloS one, 6(7), e22521.

Theimer, C. A., \& Feigon, J. (2006). Structure and function of telomerase RNA. Current opinion in structural biology, 16(3), 307-318.

Werner, C., Fürster, T., Widmann, T., Pöss, J., Roggia, C., Hanhoun, M., ... \& Haendeler, J. (2009). Physical exercise prevents cellular senescence in circulating leukocytes and in the vessel wall. Circulation, 120(24), 2438-2447.

Zhu, H., Wang, X., Gutin, B., Davis, C. L., Keeton, D., Thomas, J., ... \& Van Der Harst, P. (2011). Leukocyte telomere length in healthy Caucasian and African-American adolescents: relationships with race, sex, adiposity, adipokines, and physical activity. The Journal of pediatrics, 158(2), 215-220. 